\title{
SYSTÉM LÉČBY NA SPINÁLNÍ REHABILITAČNÍ JEDNOTCE V REHABILITAČNÍM ÚSTAVU KLADRUBY
}

\author{
Eva Talpová1, 2, Marie Kulakovská2
}

12: $352-357,2010$

ISSN 1212-4117

1Jihočeská univerzita v Českých Budějovicích, Zdravotně sociální fakulta, studentka doktorského studia Specializace ve zdravotnictví, obor Prevence, náprava a terapie zdravotní a sociální problematiky dětí, dospělých a seniorů

${ }^{2}$ Rehabilitační ústav Kladruby

\section{ÚVOD}

Léčebná rehabilitace pacientů s poraněním míchy a páteře probíhá pro svoji náročnost na spinálních jednotkách. Rehabilitace začíná ihned po úrazu a liší se intenzitou dle fáze, ve které se pacient nachází. Společným cílem celého léčebného procesu v akutní, postakutní i chronické fázi míšního poranění je snaha o maximální obnovu postižených funkcí a dosažení soběstačnosti za využití zbylého svalového potenciálu.

\section{Vývoj specializovaných zařizení}

V České republice se nejvíce zasloužil o léčení poranění míchy Vladimír Beneš. V roce 1961 vydal knihu „Poranění míchy“. Představuje ucelenou ošetřovatelskou a rehabilitační péči u paraplegiků s odkazem na anglickou školu sira Ludwiga Guttmanna (1899-1980). Postižení byli soustředěni na neurochirurgická pracoviště a tím se snížila úmrtnost z 80 na $20 \%$. Tato specializovaná oddělení v ČSSR nebyla. Mnoho odborníků se však snažilo tento jednotný systém uceleného léčení úrazů míchy zavést (Wendsche a kol., 2009).

V dubnu 1992 vznikla Spinální jednotka Úrazové nemocnice v Brně. V roce 1993 byl vytvořen Spinální program ČR, podporující vznik specializovaných pracovišt', která by zabezpečovala kvalifikovanou péči pro pacienty s poraněním a jiným onemocněním páteře. Spinální program ČR se stal součástí Národního plánu opatření pro snížení důsledků zdravotního postižení a byl přijat usnesením vlády České republiky č. 493/93. V roce 1999 byla založena Česká spondylochirurgická společnost (Wendsche a kol., 2009).

Ministerstvo zdravotnictví České republiky vydalo v červnu 2002 Metodické opatření, ve kterém je uvedena sít' spondylochirurgických pracovišt' ČR. Zde se mají léčit úrazy páteře podle nejmodernějších zásad a doporučených standardů. Navazují na ně spinální jednotky a po nich následují spinální rehabilitační jednotky v rehabilitačních ústavech (Věstník MZ ČR částka 6/2002).

V letech 2002-04 vznikly Spinální jednotky (SJ) v Ostravě, Liberci a Praze. Byla vytvořena sít' spinálních jednotek. SJ v Ostravě vznikla 1. 10. 2002 a má kapacitu 15 lůžek, SJ v Liberci vznikla 1. 1. 2003 s 15 lůžky a SJ v Praze-Motole 1. 6. 2004 se 16 lůžky (Věstník MZ ČR částka 6/2002, Spinální jednotka Fakultní nemocnice Motol, 2010).

V dubnu 2004 bylo založeno Paraplegiologické fórum, které se na podzim roku 2007 transformovalo do nové společnosti „Česká společnost pro míšní léze“ (Wendsche a kol., 2009).

\section{Česká společnost pro míšní léze}

Česká společnost pro míšní léze ČLS JEP usiluje o poskytování léčebné a rehabilitační péče občanům po míšním poškození $\mathrm{v}$ souladu $\mathrm{s}$ nejnovějšími poznatky medicíny. ČSML podporuje předávání poznatků o problematice míšního poranění odborné veřejnosti, podporuje informování laické veřejnosti, usiluje o trvalou dispenzární péči občanů s poškozením míchy, rozvijí odborné kontakty se zahraničními společnostmi (Česká společnost pro míšní léze ČLS JEP, 2010).

\section{Komplexní péče}

$\mathrm{Na}$ spondylochirurgická pracoviště, kterých je v ČR 18, navazují 4 spinální jednotky. Po nich v rámci ucelené péče následují spinální rehabilitační jednotky (SRJ), které jsou v ČR 3. Spinální rehabilitační jednotky $\mathrm{v}$ Rehabilitačním ústavu Hrabyně a v Rehabilitačním ústavu Kladruby byly otevřeny dne 1.7.2002 se stejnou kapacitou 40 lůžek. V Hamzově léčebně pro děti a dospělé funguje SRJ od roku 1993 s 24 lưžky (Věstník 
MZ ČR částka 6/2002; Spinální rehabilitační jednotka, Rehabilitační ústav Kladruby).

Spinální rehabilitační jednotka (SRJ) v Kladrubech vznikla 1. 7. 2002. Př́jem pacientů je možný od 6. týdne po vzniku onemocnění. SRJ má 40 lůžek se skupinovou ošetřovatelskou péčí. Maximální délka pobytu na SRJ je 5 měsíců. Při komplikacích je pacient překládán zpět na SJ, eventuálně na jiné specializované oddělení. Po stabilizaci zdravotního stavu se pacient vrací zpět na SRJ k dokončení rehabilitační léčby. Pokoje jsou vybaveny stavěcími polohovacími lůžky a pro pacienty oddělení jsou $\mathrm{k}$ dispozici dva motomedy do lůžka (Spinální rehabilitační jednotka, Rehabilitační ústav Kladruby, 2010).

Rehabilitační léčba probíhá od přijetí na SRJ systémem pozvolné zátěže přibližně 14 dní a poté je téměř plně převedena na rehabilitační oddělení. Na lůžkovém oddělení probíhá rehabilitační ošetřování. Jedná se o způsob aktivního ošetřování, kdy zdravotní sestra všemi dostupnými prostředky zamezuje vzniku komplikací a sekundárních změn. Každodenně spolupracuje s ergoterapeuty nebo fyzioterapeuty. Sestra nemůže nahrazovat jejich práci, ale může dle instrukcí udělat pro pacienta s omezením pohybové aktivity mnoho (Klusoňová, Pitnerová, 2005).
$\mathrm{Na}$ rehabilitačním oddělení je pacient postupně rehabilitován podle individuálního programu k maximální možné úrovni předpokládané pohybové aktivity. Fyzioterapii dělíme na léčebnou tělesnou výchovu (LTV) a fyzikální léčbu. LTV je prováděna individuálně nebo ve skupinách. Ve fyzikální léčbě se využívá stejnosměrných a střídavých proudů, parafínu, laseru, magnetického vlnění a mnoha dalších metod. Součástí rehabilitace je ergoterapie, která je zaměřena na minimalizaci nedostatků, které vznikly onemocněním. Jedná se o výběr vhodných kompenzačních pomůcek, nácvik denních potřeb - oblékání, psaní, osobní hygieny (Seidl, Obenberger, 2004).

\section{Spinální rehabilitační jednotka v Rehabilitačním ústavu Kladruby}

Provoz Spinální rehabilitační jednotky (dále SRJ) v Rehabilitačním ústavu (dále RÚ) Kladruby od poloviny roku 2002 do poloviny roku 2009.

Za 7 let provozu bylo na Spinální rehabilitační jednotce Rehabilitačního ústavu Kladruby léčeno 798 pacientů s čerstvým míšním postižením. Z toho 594 mužů a 204 žen. Poměr léčených mužů a žen je 3:1. Průměrný věk léčených pacientů byl 45 let (tab. 1).

Tabulka 1 Počty pacientů a jejich průměrný věk

(SRJ RÚ Kladruby v období od poloviny r. 2002 do poloviny r. 2009)

\begin{tabular}{lrrrc}
\hline rok & celkem & muži & ženy & prům. věk \\
\hline $1 / 22002$ & 65 & 52 & 13 & 28 \\
2003 & 117 & 96 & 21 & 39 \\
2004 & 101 & 78 & 23 & 51 \\
2005 & 109 & 75 & 34 & 48 \\
2006 & 116 & 82 & 34 & 48 \\
2007 & 117 & 82 & 35 & 46 \\
2008 & 112 & 86 & 26 & 44 \\
$1 / 22009$ & 61 & 43 & 18 & 44 \\
celkem & 798 & 594 & 204 & 45 \\
\hline
\end{tabular}

Zdroj: statistika Rehabilitační ústav Kladruby 
Téměř u poloviny pacientů se jednalo o poranění úseku krční páteře (C). Pokračovalo poranění úseku hrudní páteře (Th), úseku bederní páteře (L), úseku sakrální páteře (S). Následkem uvedených poranění je ve většině př́ipadů tetraplegie, tetraparéza, paraplegie, paraparéza (tab. 2). Jedná se o diagnózy s trvalými následky pro pacienty. Tetraplegie je z hlediska léčby nejnáročnější diagnózou. Pacienti s tímto postižením musí věnovat veškeré síly ke zvládnutí základních denních činností. Potřebují vzhledem $\mathrm{k}$ závažnosti onemocnění tu největší pomoc.

Tabulka 2 Složení pacientů podle výšky postižení

(SRJ RÚ Kladruby v období od poloviny r. 2002 do poloviny r. 2009)

\begin{tabular}{lcccc}
\hline rok & C & Th & L & S \\
\hline $1 / 22002$ & 30 & 16 & 19 & 0 \\
2003 & 53 & 30 & 34 & 0 \\
2004 & 45 & 33 & 22 & 1 \\
2005 & 31 & 53 & 23 & 2 \\
2006 & 55 & 48 & 13 & 0 \\
2007 & 50 & 49 & 18 & 0 \\
2008 & 55 & 39 & 17 & 1 \\
$1 / 22009$ & 26 & 26 & 9 & 0 \\
celkem & 345 & 294 & 155 & 4 \\
\hline & & & Zdroj: statistika Rehabilitační ústav Kladruby
\end{tabular}

Legenda: $C$-úsek krční páteře, Th-úsek hrudní páteře, L-úsek bederní páteře, $S$-úsek sakrální páteře.

U lékařského vyšetření spinálního pacienta se celosvětově $\mathrm{k}$ hodnocení používá ASIA (American Spinal Injury Association) klasifikace - Standard pro neurologickou klasifikaci spinálního poranění. Dělí se na hodnocení neurologické úrovně léze (podle motorické a senzitivní úrovně) a na rozsah léze (ASIA Impairment Scale - zkratka AIS A-E). Zařazení a počty pacientů jsou uvedeny v tab. 3. E znamená bez neurologického deficitu, $v$ tabulce 3 není uvedeno, jelikož do této kategorie nebyl zařazen žádný pacient.

Tabulka 3 ASIA skóre a počet vozíků

(SRJ RÚ Kladruby v období od poloviny r. 2002 do poloviny r. 2009)

\begin{tabular}{lccccc}
\hline rok & ASIA & & & & počet vozíků \\
\hline $1 / 22002$ & A & B & C & D & 50 \\
2003 & 33 & 17 & 15 & 0 & 74 \\
2004 & 53 & 21 & 43 & 0 & 84 \\
2005 & 57 & 27 & 17 & 0 & 67 \\
2006 & 37 & 16 & 28 & 28 & 85 \\
2007 & 39 & 25 & 40 & 12 & 79 \\
2008 & 48 & 13 & 44 & 12 & 71 \\
$1 / 22009$ & 36 & 9 & 27 & 40 & 46 \\
celkem & 19 & 2 & 30 & 10 & 556 \\
\hline & 322 & 130 & 244 & 102 & Zdroj: statistika Rehabilitační ústav Kladruby
\end{tabular}

Zdroj: statistika Rehabilitační ústav Kladruby 
Legenda: A - kompletní motorická a senzitivní léze pod úrovní poranění včetně S4-S5 segmentů, B kompletní motorická léze, zachována citlivost pod úrovní léze včetně S4-S5 segmentü, ale není zde žádná motorická funkce, $\boldsymbol{C}$-nekompletní léze, kdy motorická funkce je zachována u více než poloviny klíčových svalů pod neurologickou úrovní, a to na stupni méné než 3. D-nekompletní léze, kdy motorická funkce u více než poloviny klíčových svalů pod neurologickou úrovní je na stupni 3 a více.

Nejčastější příčinou poranění byl úraz, následoval zánět, tumor, cévní onemocnění a jiné. V posledních pěti letech vzrostl počet zánětů (tab. 4). Nejčastějším mechanismem úrazu byly pády, následovaly autonehody a úrazy při sportu (tab. 5). Těsně za úrazy při sportu se umístily úrazy ve vodě. Právě mezi ně patří skoky po hlavě do neznámé vody, které mívají za následek poškození míchy $\mathrm{v}$ úseku krční páteře s následky tetraplegie. Rozhodli jsem se, že $\mathrm{s}$ prríčinami tohoto a dalších úrazů budeme seznamovat skupiny dospívajících $\mathrm{v}$ preventivních programech s názvem „Na vlastní kůži““ prímo v RÚ Kladruby. Účastníci si mohou vyzkoušet jízdu na vozících a prostřednictvím diskuse s pacienty se setkat se skutečnými př́pady $\mathrm{s}$ cílem přestat vnímat možnost úrazu jako něco abstraktního.

Tabulka 4 Složení pacientů podle příčiny vzniku postižení

(SRJ RÚ Kladruby v období od poloviny r. 2002 do poloviny r. 2009)

\begin{tabular}{|c|c|c|c|c|c|c|c|c|c|}
\hline & $\begin{array}{c}1 / 2 \\
2002 \\
\end{array}$ & 2003 & 2004 & 2005 & 2006 & 2007 & 2008 & $\begin{array}{c}1 / 2 \\
2009\end{array}$ & celkem \\
\hline úrazy & 50 & 81 & 82 & 81 & 92 & 89 & 89 & 37 & 601 \\
\hline zánět & 3 & 5 & 0 & 7 & 12 & 11 & 13 & 14 & 65 \\
\hline tumor & 6 & 12 & 9 & 5 & 4 & 7 & 5 & 3 & 51 \\
\hline cévní & 3 & 7 & 1 & 9 & 6 & 7 & 5 & 7 & 45 \\
\hline jiné & 3 & 12 & 9 & 7 & 2 & 3 & 0 & 0 & 36 \\
\hline celkem & 65 & 117 & 101 & 109 & 116 & 117 & 112 & 61 & 798 \\
\hline
\end{tabular}

Zdroj: statistika Rehabilitační ústav Kladruby

Tabulka 5 Složení pacientů podle mechanismu úrazu

(SRJ RÚ Kladruby v období od poloviny r. 2002 do poloviny r. 2009)

\begin{tabular}{|c|c|c|c|c|c|c|c|c|c|}
\hline & $\begin{array}{c}1 / 2 \\
2002\end{array}$ & 2003 & 2004 & 2005 & 2006 & 2007 & 2008 & $\begin{array}{c}1 / 2 \\
2009\end{array}$ & celkem \\
\hline pád & 13 & 19 & 34 & 37 & 35 & 32 & 37 & 17 & 224 \\
\hline auto & 12 & 32 & 26 & 25 & 29 & 26 & 21 & 9 & 180 \\
\hline sport & 10 & 15 & 5 & 4 & 11 & 6 & 14 & 6 & 71 \\
\hline voda & 10 & 10 & 7 & 8 & 9 & 10 & 9 & 3 & 66 \\
\hline jiné & 5 & 5 & 10 & 7 & 8 & 15 & 8 & 2 & 60 \\
\hline celkem & 50 & 81 & 82 & 81 & 92 & 89 & 89 & 37 & 601 \\
\hline
\end{tabular}

Zdroj: statistika Rehabilitační ústav Kladruby

Postižení provázejí další zdravotní komplikace. Nejčastějšími zjišš̌nými při léčbě byly uroinfekce a dekubity, na třetím místě pak deprese (tab. 6). Poranění míchy zásadně zasahuje do života jedince. Jeho naplánovaný a většinou uspěchaný životní rytmus je přerušen. Ocitá se v neznámém prostředí odkázaný na pomoc druhých, se strachem z budoucnosti. V tomto 
období významně pomáhá péče psychologů, kteři jsou členy multidisciplinárního týmu. U tetraplegických pacientů nastávají po trache- ostomii poruchy řeči a dýchání, které vyžadujî logopedickou péči.

Tabulka 6 Komplikace léčby

(SRJ RÚ Kladruby v období od poloviny r. 2002 do poloviny r. 2009)

\begin{tabular}{|c|c|c|c|c|c|c|c|c|c|}
\hline & $\begin{array}{c}1 / 2 \\
2002 \\
\end{array}$ & 2003 & 2004 & 2005 & 2006 & 2007 & 2008 & $\begin{array}{c}1 / 2 \\
2009 \\
\end{array}$ & celkem \\
\hline dekubity & 10 & 29 & 41 & 21 & 10 & 11 & 12 & 10 & 144 \\
\hline uroinfekce & 18 & 39 & 20 & 12 & 5 & 12 & 10 & 11 & 127 \\
\hline deprese & 4 & 4 & 5 & 6 & 9 & 5 & 6 & 2 & 41 \\
\hline spasticita & 7 & 3 & 4 & 5 & 8 & 3 & 2 & 5 & 37 \\
\hline flebotrombózy & 1 & 2 & 1 & 3 & 4 & 4 & 4 & 2 & 21 \\
\hline MRSA & 0 & 0 & 0 & 4 & 4 & 5 & 3 & 4 & 20 \\
\hline kalcifikace & 3 & 4 & 4 & 3 & 2 & 2 & 0 & 1 & 19 \\
\hline pneumonie, ICD & 0 & 1 & 1 & 0 & 0 & 3 & 2 & 3 & 10 \\
\hline reoperace & 1 & 2 & 0 & 0 & 0 & 2 & 1 & 1 & 7 \\
\hline
\end{tabular}

V průběhu pobytu jsou pacienti vybavováni za pomoci fyzioterapeutů a ergoterapeutů prostředky zdravotnické techniky. Pomůcky si zkoušejí v ústavu, ale mohou si je zapůjčit i k odzkoušení domů. $\mathrm{V}$ ústavu je $\mathrm{k}$ dispozici obchod se zdravotními potřebami, protetické oddělení a cvičný byt - léčba k soběstačnosti. $\mathrm{V}$ bytě pacienti nacvičují $\mathrm{v}$ rámci ergoterapie zvládání denních činností, nezbytných k soběstačnosti po návratu domů. Většina uvedených pacientů potrebovala pro další život vozík. Pro 556 pacientů byl k soběstačnosti nezbytný (tab. 3).

Skupina tetraplegiků bude potřebovat mimo vozíku i mnoho dalších pomůcek. Ze zkušenosti uvádíme elektrické lůžko nejlépe stavěcí, antidekubitní podložku do vozíku i lůžka, sprchový vozík nebo zvedák do vany a další.

Uvedené pomůcky však nestačí. Pokud se jedná o pacienta s porušenou míchou, změna životního stylu je zásadní a týká se mnoha oblastí. Ve většině prrípadů je nutná úprava nebo výměna bytu, zajištění sociální pomoci a poradenství v dalších otázkách. S pacienty a jejich rodinami řeší tyto problémy zdravotně sociální pracovnice $\mathrm{v}$ průběhu pobytu.

Z celkového počtu 798 prrijatých pacientů na spinální rehabilitační jednotku bylo 471 přijato prímo ze spinálních jednotek. Z údajů v tab. 7 je patrné, že od roku 2004 se procento prímo překládaných pacientů zvyšuje. 
Tabulka 7 Počet pacientů, kteří na SRJ nastoupili ze SJ

(SRJ RÚ Kladruby v období od poloviny r. 2002 do poloviny r. 2009)

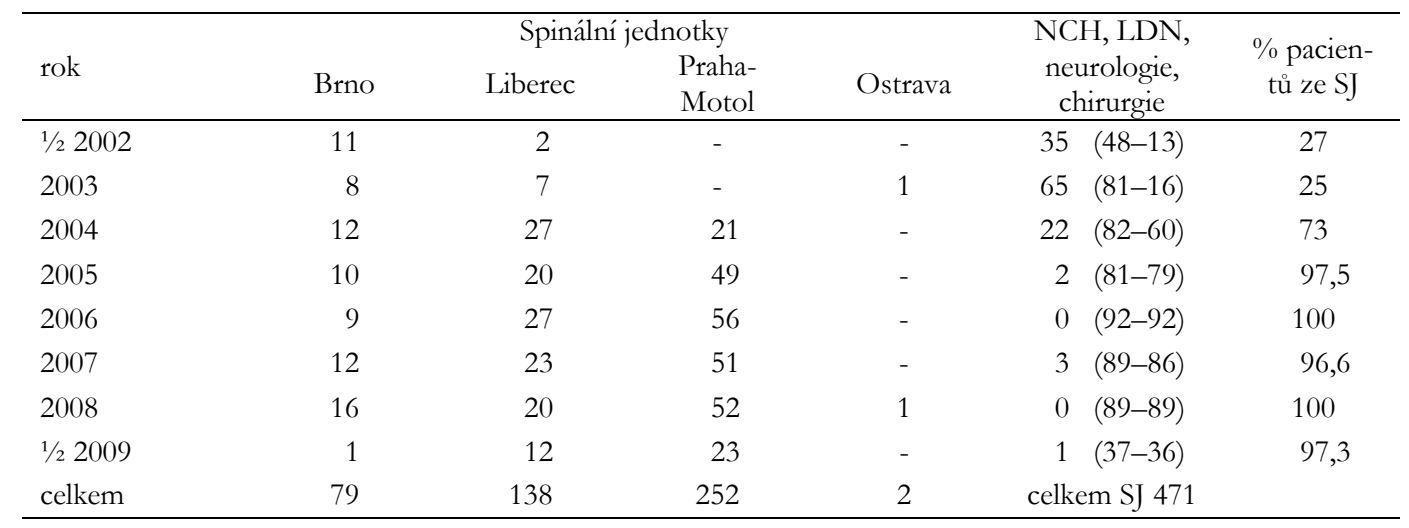

Zdroj: statistika Rehabilitační ústav Kladruby

Legenda: NCH - neurochirurgie, LDN-léčebna dlouhodobě nemocných

\section{ZÁVĚR}

Sít' specializovaných zařízení - spondylochirurgických pracovišt' v akutní fázi, spinálních jednotek v postakutní fázi a spinálních rehabilitačních jednotek v chronické fázi - je nezbytná pro léčbu pacientů s míšním poraněním. Jak je patrné z výsledků (tab. 7), počet pacientů ze spinálních jednotek, kteří byli prrijati přímo na Spinální rehabilitační jednotku do Rehabilitačního ústavu Kladruby, se od roku 2004 zvyšuje. Stále se však vyskytují př́ipady, kdy jsou pacienti chybně umístěni na jiná oddělení, nejčastěji spádové neurologie, léčebny dlouhodobě nemocných. O těchto pacientech se dozvídáme od rodinných př́islušníků nebo lékařu těchto oddělení, kteří žádají jejich rehabilitaci v našem zařízení.

O stále větší informovanost se snaží Česká společnost pro míňní léze. Zkušenosti odborníků z popisovaných specializovaných pracovišt' jsou prezentovány mimo jiné na spinálních kongresech, které jsou organizovány některým ze zařízení $1 \times$ za 2 roky.

Zástupci vybudované a schválené sítě specializovaných zařízení spolu úzce komunikují, respektují fáze průběhu míšního postižení a řídí se společnými postupy.

Návrat k běžnému způsobu života závisí na typu zdravotního/tělesného postižení a mnoha dalších faktorech. Pokročilé technologie prri dobře organizované rehabilitaci kompenzují velké zdravotní problémy. Provádění různých složek rehabilitace je koordinované (Zeman, 2009). Podpora osob se zdravotním postižením musí být soustavná a provázaná i po opuštění rehabilitačního zařízení.

\section{LITERATURA}

Česká společnost pro míšní léze ČLS JEP. [online]. Poslední aktualizace neuvedena. [cit.2010/01/18]. Dostupné z: http://www.spinalcord.cz/cz/o-spolecnosti/ cile-a- vyznam/

KLUSOŇOVÁ, E., PITNEROVÁ, J.: Rehabilitační ošetrování pacienti̊ s těžkými poruchami hybnosti. 2. vyd. Brno: Národní centrum ošetřovatelství a nelékařských zdravotnických oborů, 2005, s. 9.

SEIDL, Z., OBENBERGER, J.: Neurologie pro studium i praxi. 1. vyd. Praha: Grada Publishing, a. s., 2004, s. 344-346.

Spinální jednotka Fakultní nemocnice Motol. [online]. Poslední aktualizace neuvedena. [cit.2010-01-18]. Dostupné z: http://www.fnmotol.cz/spinalni-jednotka2.html?pracoviště $=52$

Spinální rehabilitační jednotka, Rehabilitační ústav Kladruby. [online]. Poslední aktualizace neuvedena. [cit.2010-01-18]. Dostupné z: http://www.rehabilitace.cz/ open/spinalni.htm

Věstník MZ ČR částka 6/2002 z června 2002.

WENDSCHE, P. a kol.: Poranění míchy - ucelená ošetrovatelsko-rehabilitační péče. 2. vyd. Brno: Národní centrum ošetřovatelství a nelékařských zdravotnických oborů, 2009, s. 9.

ZEMAN, M.: Fyzioterapie v současné moderní medicíně. In: Kontakt, 2009, roč. 11, č. 2.

Eva Talpová, Marie Kulakovská E.Talpova@seznam.cz

Kontakt 3/2010 